\title{
ANALISIS PENERAPAN RANTAI PASOK TERHADAP MANAJEMEN PEMBIAYAAN PROYEK KONTRUKSI BANGUNAN GEDUNG X DI JAKARTA
}

\author{
Mukhamad Risa Diki Pratama \\ Universitas Indraprasta PGRI, Program Studi Arsitektur \\ mrdikipratama1@gmail.com
}

\begin{tabular}{|c|c|c|}
\hline Informasi arti & & ABSTRAK \\
\hline $\begin{array}{l}\text { Sejarah } \\
\text { artikel: }\end{array}$ & & \multirow{8}{*}{$\begin{array}{l}\text { Pada proyek konstruksi bangunan gedung, waktu dan biaya berperan penting } \\
\text { untuk memberikan berhasil tidaknya suatu proyek. Salah satu permasalahan } \\
\text { saat ini pada proyek konstruksi yang harus di perhatikan yaitu manajemen } \\
\text { biaya. Hal tersebut membutuhkan beberapa cara untuk melancarkan proyek } \\
\text { banguanan gedung tersebut. Material kurang tersedia, pencapaian yang sulit di } \\
\text { tempuh hal ini tentu secara tidak langsung mempengaruhi berjalannya proyek } \\
\text { konstruksi bangunan gedung. Penerapan rantai pasok yang efisien menunjukan } \\
\text { keberhasilan proyek, waktu dan biaya akan berjalan seperti yang sudah } \\
\text { direncanakan dan disetujui. Metode yang digunakan dalam penelitian ini adalah } \\
\text { metode kuantitatif dengan mengkaji beberapa artikel yang relavan. } \\
\text { Berdasarkan analisa tersebut beberapa faktor yang sangat terpengaruh } \\
\text { diantaranya kesediaan material yang kurang, kesesuaian data, fasilitas } \\
\text { penunjang dan mengadakan keselamatan. }\end{array}$} \\
\hline Diterima & 28 Februari 2021 & \\
\hline Revisi & 28 Maret 2021 & \\
\hline Dipublikasikan & 30 Maret 2021 & \\
\hline \multirow{5}{*}{\multicolumn{2}{|c|}{$\begin{array}{l}\text { Kata kunci: } \\
\text { Rantai pasok } \\
\text { Manajemen pembiayaan proyek } \\
\text { Kontruksi } \\
\text { Bangunan gedung }\end{array}$}} & \\
\hline & & \\
\hline & & \\
\hline & & \\
\hline & & ABSTRACT \\
\hline \multirow{4}{*}{\multicolumn{2}{|c|}{$\begin{array}{l}\text { Key word: } \\
\text { Supply chain } \\
\text { Cost manajement } \\
\text { Contruction } \\
\text { Building }\end{array}$}} & $\begin{array}{l}\text { In bulding project, time and cost is very important thing to give the result goal of } \\
\text { project. One of many problems in the construction project that must be very }\end{array}$ \\
\hline & & important thing to watch to smooth out the building project. The uncompletely \\
\hline & & material, the dificulty goal of the project, absolutely may impact the building \\
\hline & & $\begin{array}{l}\text { process. The efficient applicatiton supply chain show the success full project, time } \\
\text { and cost will be run as well as we plan. The result method of this research is } \\
\text { quantitative method with examine some relevant articles. Based on the analysis of } \\
\text { many factor which is very affected between minim materials, suitability of file, } \\
\text { supporting facilities and savety. }\end{array}$ \\
\hline
\end{tabular}

\section{PENDAHULUAN}

Rantai pasok merupakan industri konstruksi yang dapat diambil dari konsep yang awalnya berasal dari industri manufaktur untuk mendapatkan pencapaian dari efisiensi mutu, waktu dan biaya yang bisa meningkatkan hasil dalam pelaksanaan pekerjaan konstruksi (Juarti, 2008).

Rantai pasok memiliki hubungan dengan berbagai pihak, diantaranya hubungan hulu (upstream) hingga ke hilir (downstream), dalam proses untuk mendapatkan barang dan jasa yang berbeda dan juga penting sampai kepada pelanggan akhir. Sehingga kemungkinan keterlibatan dari beberapa pihak akan membentuk suatu hubungan yang dapat menempatkan pihak berposisi salah satu alur dalam suatu rangkaian rantai proses yang menghasilkan produk konstruksi (Vrijhoef, 1999).

Adanya keikutsertaan beberapa bagian dengan keahlian dan kepentingan yang berbeda-beda akan memperlihatkan terpecahnya suatu pekerjaan konstruksi ke dalam sebagian paket pekerjaan yang dilakukan oleh sebagian yang berbeda, sehingga suatu pola rantai pasok terjadi beberapa masalah, seperti pembekakan pada biaya pelaksanaan, terjadinya lambatnya pekerjaan, terjadinya perselisihan, sehingga mengakibatkan industri konstruksi dilihat sebagai industri yang kutang efisien (Tucker., 2001).

Pengelolaan rantai pasok yang sukses membutuhkan sistem yang terintegrasi. Masing-masing unit dalam rantai pasok menjadi satu kesatuan, tidak berdiri sendiri-sendiri sebagaimana halnya dengan rantai pasok tradisional. Kegiatan operasi pada rantai pasok membutuhkan aliran informasi 
yang berkesinambungan untuk menghasilkan produk yang baik pada saat yang tepat sesuai dengan kebutuhan konsumen ( Stock dan Lambert 2001).

Dari latar belakang terdapat hubungan antara keberhasilan proyek konstruksi bangunan dengan rantai pasok, maka dari itu rumusan masalah penelitian ini adalah faktor apa saja yang mempengaruhi tidak kesesuaian terhadap proyek konstrksi bangunan gedung?

Penelitian ini dilakukan untuk meminimalisir perbedaan pembiayaan anatara rencana anggaran dengan terealisasinya proyek konstruksi bangunan.

\section{Rantai Pasok}

Rantai pasok merupakan suatu proses proses yang dimulai dari pengumpulan sumber daya yang ada dilanjutkan dengan pengelolaan menjadi produk jadi untuk selanjutnya didistribusikan dan dipasarkan sampai pelanggan akhir dengan memperhatikan biaya, kualitas, ketersediaan, pelayanan purna jual, dan faktor reputasi. Rantai pasok melibatkan supplier, manufacturer, dan retailer yang saling bersinergis dan bekerja sama satu sama lain secara langsung maupun tidak langsung. (Wisner, Tan, dan Leong, 2012, p. 6)

Sebuah rantai pasok terdiri dari semua pihak yang terlibat, baik langsung maupun tidak langsung, dalam memenuhi permintaan pelanggan. Rantai pasok meliputi tidak hanya produsen dan pemasok, tetapi juga pengangkut, gudang, pengecer, dan bahkan pelanggan sendiri. Dari masingmasing organisasi, seperti produsen, rantai pasok mencakup semua fungsi yang terlibat dalam menerima dan memenuhi permintaan pelanggan. Fungsi ini menyeluruh namun tidak terbatas pada pengembangan produk baru, pemasaran, operasi, distribusi, keuangan, dan layanan pelanggan (Chopra, Meindl, 2010, p.20). Terdapat hubungan erat antara desain dan manajemen aliran rantai pasokan (produk, informasi, dan dana) (Chopra, Meindl, 2010, p.23).

\section{Manajemen pembiayaan proyek}

Dalam proyek konstruksi terdapat manajemen biaya proyek yang mencakup proses-proses yang diperlukan untuk memastikan bahwa proyek kontsruksi dapat diselesaikan dalam anggaran yang disetujui. Manajemen biaya proyek biasanya dikaitkan dengan biaya sumber daya, hal ini yang diperlukan untuk menyelesaikan kegiatan proyek.

Namun, manajemen biaya proyek juga harus mempertimbangkan dampak keputusan proyek mengenai biaya penggunaan produk proyek. Sebagai contoh, membatasi jumlah resensi desain dapat mengurangi biaya proyek terhadap pengeluaran untuk meningkatkan biaya operasional pelanggan. Persepsi ini dalam manajemen biaya proyek sering disebut siklus hidup biaya. Siklus hidup biaya bersama-sama dengan nilai rekayasa teknik yang digunakan untuk mengurangi biaya waktu, meningkatkan kualitas dan kinerja dan mengoptimalkan pengambilan keputusan.

\section{Konstruksi}

Konstruksi merupakan suatu kegiatan membangun sarana maupun prasarana. Dalam bidang arsitektur atau teknik sipil, sebuah konstruksi juga dikenal sebagai bangunan atau satuan infrastruktur pada sebuah area atau pada beberapa area. Secara ringkas konstruksi didefinisikan sebagai objek keseluruhan bangunan yang terdiri dari bagian-bagian struktur. Misal, Konstruksi Struktur Bangunan adalah bentuk/bangun secara keseluruhan dari struktur bangunan. contoh lain: Konstruksi Jalan Raya, Konstruksi Jembatan, Konstruksi Kapal, dan lain lain.

Konstruksi dapat juga didefinisikan sebagai susunan (model, tata letak) suatu bangunan (jembatan, rumah, dan lain sebagainya) Walaupun kegiatan konstruksi dikenal sebagai satu pekerjaan, tetapi dalam kenyataannya konstruksi merupakan satuan kegiatan yang terdiri dari beberapa 
pekerjaan lain yang berbeda.Pada umumnya kegiatan konstruksi diawasi oleh manajer proyek, insinyur disain, atau arsitek proyek. Orang-orang ini bekerja di dalam kantor, sedangkan pengawasan lapangan biasanya diserahkan kepada mandor proyek yang mengawasi buruh bangunan, tukang kayu, dan ahli bangunan lainnya untuk menyelesaikan fisik sebuah konstruksi.

\section{Bangunan Gedung}

Definisi bangunan gedung menurut Undang-undang no. 28 tahun 2002 tentang bangunan gedung dijelaskan pada pasal 1. Bangunan gedung adalah wujud fisik hasil pekerjaan konstruksi yang menyatu dengan tempat kedudukannya, sebagian atau seluruhnya berada di atas dan/atau di dalam tanah dan/atau air, yang berfungsi sebagai tempat manusia melakukan kegiatannya, baik untuk hunian atau tempat tinggal, kegiatan keagamaan, kegiata usaha, kegiatan sosial, budaya, maupun kegiatan khusus.

Berdasarkan pasal 1 diatas, fungsi bangunan gedung dibedakan menjadi beberapa macam. Penggolongan bangunan gedung menurut fungsinya diatur dalam UU no. 28 tahun 2002 tentang bangunan gedung pasal 5

\section{METODOLOGI}

Penelitian ini mencoba untuk menganalisis penggunaan rantai pasok untuk meningkatkan manajemen pembiayaan dalam tahap pelaksanaan pada bangunan gedung. Tahap pertama adalah mengumpulkan beberapa hasil penelitian yang relevan. Langkah kedua adalah mengkaji artikel artikel yang di mana faktor apa yang paling berpengaruh dari data - data yang didapatkan. Langkah ketiga membuat kesimpulan dari tahap penelitian.

\section{HASIL DAN PEMBAHASAN}

Pengaruh Rantai Pasok Terhadap Kinerja Kontraktor Di Propinsi Banten Dan DKI Jakarta ( Andi M, Irma S, Oktaviana K.A, 2018). Artikel ini bertujuan untuk mengetahui Faktor-faktor rantai pasok konstruksi di Provinsi Banten dan DKI Jakarta meliputi aliran informasi, aliran material, dan aliran finansial. Terdapat 24 indikator rantai pasok yang berpengaruh terhadap kinerja kontraktor. Aliran informasi dan material berpengaruh positif terhadap kinerja kontraktor, aliran finansial tidak berpengaruh terhadap kinerja kontraktor. Perjanjian jangka panjang, sistem pembelian konsinyasi serta anak perusahaan dari pemasok adalah hal-hal yang menguatkan aliran finansial tidak berpengaruh signifikan. Semakin tinggi pengelolaan aliran informasi dan material semakin tinggi kinerja kontraktor. Aliran informasi mempunyai pengaruh positif $(0,725)$ terhadap kinerja kontraktor dibandingkan aliran material $(0,471)$.

Aplikasi Rantai Pasok Pengadaan Material Kontruksi Antar Pulau ( M. Nur Sholeh, M. Agung Wibowo, 2015). Artikel ini membahas hasil analisa dan pembahasan yang disimpulkan bahwa pekerjaan konstruksi sangat membutuhkan kemudahan dalam pengadaan material. Konsep rantai pasok konstruksi sangat membantu kesuksesan proyek. Melihat kondisi Indonesia yang terdiri atas pulaupulau maka dalam menunjang MP3EI (Master Plan Percepatan Pembangunan Ekonomi Indonesia) secara terintegrasi. Konsep Integrasi rantai pasok antar pulau yang harus dikembangkan adalah:

- Pola distribusi material konstruksi yang baik sehingga memudahkan konraktor dalam pengadaan material.

- Pengadaan material yang efektif akan menjaga kenaikan harga material yang drastis dan menjaga mutu agar tetap baik. 
Urgensi Penelitian Manajemen Rantai Pasok: Pemetaan Isu, Objek, Dan Metodologi (Sherlywati, 2018). Artikel ini bertujuan menyarankan agar peneliti yang berkecimpung di bidang SCM melakukan update dan upgrade kapasitas, informasi, serta pengetahuan mengenai perkembangan kajian manajemen rantai pasokan secara berkelanjutan. Hal ini difokuskan bagi kalangan peneliti baik di lingkungan akademisi, sektor privat, dan sektor publik. Saat ini, cakupan SCM semakin luas dan keterkaitan dengan bidang ilmu lainnya tidak bisa dielakkan. Untuk itu, sensitivitas peneliti dalam menangkap fenomena permasalahan SCM yang sedang terjadi perlu diasah dengan mengetahui bidang kajian lain yang terkait dengan kajian SCM. Bidang kajian yang tidak dapat dilepaskan dengan SCM ini akan memberikan nilai tambah dalam pengelolaan manajemen rantai pasok perusahaan. Bidang kajian tersebut misalnya seperti manajemen risiko, manajemen kualitas, manajemen sumber daya manusia, manajemen keuangan, teknologi informasi, kebijakan-kebijakan publik, dan lainnya.

Analisis Nilai Hasil Terhadap Waktu Dan Biaya Pada Proyek Kontruksi (Ardiansyah K, 2016). Berdasarkan hasil pengamatan Artikel ini bertujuan untuk mengetahui pengambilan data dan analisa data pada proyek Pembangunan Gedung Pendidikan Fakultas Pertanian Universitas Hasanuddin., maka dapat ditarik kesimpulan sebagai berikut:

- Dalam konsep nilai hasil (earned value), diperoleh perkiraan waktu penyelesaian proyek (ECD) selama 14 minggu. Hal ini menunjukkan penyelesaian proyek lebih lambat dari jadwal yang direncanakan.

- Crashing Program Dengan menggunakan metode produktivitas dengan mengacu pada kinerja rata-rata pada minggu ke-5 sampai ke-11 didapatkan durasi proyek 18 minggu. Untuk mempercepat durasi proyek diadakan crash program dengan menambah jam kerja pekerja sebanyak 8 jam sehingga durasi proyek dipercepat menjadi 14 minggu.

Analisis Struktur Rantai Pasok Kontruksi Pada Pekerjaan Jembatan. (Febiana Maulana, Akhmad Suraji, Bambang Istijono, 2014). Tujuan dari penelitian ini adalah untuk mengetahui kinerja suatu kontraktor pada suatu proyek kontruksi jembatan dengan mengkaji melalui struktur rantai pasok yang digunakan. Hasil dari penelitian yang dilakukan pada kontraktor, subkontraktor dan supplier pada konstruksi jembatan dengan beberapa aspek penentu seperti hubungan dengan subkontraktor dan supplier seperti, jenis pengadaan, jenis kontrak, system pembayaran, dan interaksi antara dua perusahaan menunjjukn adanya keterkaitan antara hubungan kerja sama yang baik terhadap keefektifan pelaksanaan pekerjaan konstruksi.

Studi Optimasi Waktu dan Biaya Dengan Metode Time Cost Trade Off Pada Proyek Konstruksi Pembangunan Gedung Olah Raga (Gor). (Mandiyo, Meiki R, 2018). Aritikel ini mengunakan Analisis data yang dilakukan dengan bantuan program Microsoft Project 2010. Data akan input dan dianalisis dalam program, sehingga program akan menganalisis hasil dari data tersebut secara otomatis sesuai dengan rumus kalkulasi yang ada dalam program Microsoft Project 2010. Pada proses input data tahap analisis ini menggunakan dua tahapan, yaitu pertama dengan menyusun jadwal rencana dan biaya proyek (baseline) serta memasukkan durasi optimasi penambahan jam kerja (lembur).

Pengendalian Waktu Dan Biaya Pekerjaan Konstruksi Sebagai Dampak Dari Perubahan Desain. (Yunita A, Lazry H, Dantje A, 2013). Tujuan penelitian ini adalah menggambarkan pengendalian terhadap pengaruh perubahan desain yang memberikan dampak pada waktu dan biaya pekerjaan konstruksi yang mempengaruhi kinerja dari pekerjaan konstruksi Embung Irigasi Oenaem. Penelitian ini menggunakan dua metode pengendalian yaitu Earned Value Analysis (EVA) dan diintegrasikan metode pemendekan durasi jalur kritis (Crashing Duration) pada Critical Path Methode (CPM) 
menggunakan penerapan kerja lembur sebagai alternatif pengendalinya. Penggunaan kedua metode tersebut di atas maka dapat diketahui dan diperoleh alternatif pengedalian waktu dan biaya pekerjaan konstruksi sebagai dampak dari perubahan desain yang terjadi pada Proyek Pembangunan Embung Irigasi Oenaem.

Pengendalian Biaya Dan Waktu Proyek Dengan Metode Konsep Nilai Hasil (Earned Value). (Rifqi A, Daniar R, Suharyanto, Frida K, 2017). Artikel ini dilakukan untuk menganalisis kinerja suatu proyek dengan membuat perkiraan mengenai kinerja proyek pada suatu periode pelaporan yang menghasilkan estimasi biaya dan waktu untuk penyelesaian suatu proyek berdasarkan indikator saat pelaporan, maka jika ada penyimpangan kinerja pihak kontraktor bisa mengatisipasinya.. Selanjutnya data-data yang telah dikumpulkan dapat dianalisa. Pada penilitan ini data biaya pelaksanaan proyek (ACWP) adalah hasil dari laporan biaya bulanan, tidak didetailkan pada setiap item pekerjaan.

Analiasa Pengaruh Cost Menejemen Terhadap Efisiensi Pada Proyek Kontruksi Studi Pada Perusahaan PT. Adhi Karya (Persero) Tbk. (Rahmawati Eka P, 2012). Penelitian ini mengungkapkan bahwa Teori utama cost management (Kasem dan Alhaffar, 2011) sesuai dengan hasil penelitian. Pengaplikasian teori tersebut dapat terlihat pada tiap variabel independennya, yaitu cost estimate (variabel estimasi biaya), cost budget (variabel manajemen kontrak dan biaya mesin), serta cost control (variabel pengalaman project manager, fluktuasi harga bahan, dan dana owner). Teori manajemen biaya tersebut didukung oleh teori project management (Phillips, 2010) yang mensinkronkan teori manajemen biaya secara ekonomi dengan aplikasi teknis pada proyek konstruksi. Pada teori manajemen proyek tersebut terdapat tolok ukur efisiensi yang dapat dilihat pada nilai Cost Performance Index (CPI) yang dijelaskan pula oleh Khamidi (2011).

Analisa Kinerja Biaya Dan Waktu Pada Pelaksanaan Proyek Konstruksi Dengan Metode Earned Value (Studi Kasus Proyek Konstruksi Mall Dan Hotel X Di Pekanbaru).“ (Sediyanto, Aris H, 2017). Artikel ini bertujuan untuk mengetahui Dari referensi penelitian lain optimasi jadwal pelaksaanaan proyek akan lebih baik bila menggunakan evaluasi dengan metode Critical Path Metode dimana jumlah waktu yang dibutuhkan untuk menyelesaikan tahap pekerjaan dapat diketahui dengan pasti, sehingga jadwal pelaksanaan menjadi lebih optimal. Diperlukannya integrasi antara kurva S dan CPM untuk mengevaluasi jadwal pelaksanaan proyek yang lebih baik.

Dari artikel yang sudah di dapat kan faktor yang paling berpengaruh dalam meningkatkan manajemen pembiayaan proyek bahwa faktor material, faktor fasilitas, faktor kesesuaikan data terhadap proyek dan faktor keselamatan.

\section{PENUTUP}

Dari hasil dan pembahasan di atas dapat disimpulkan bahwa dalam rantai pasok memiliki faktor-faktor yang berdampak dalam peningkatan dalam manajemen pembiayaan proyek, beberapa faktor yang sering kali terabaikan dan tidak dievaluasi secara matang sehingga tujuan dari pembiayaan proyek tidak sesuai dengan apa yang diharapkan. Rantai pasok ini dapat meminimalisir faktor - faktor yang kurang tepat terhadap pembiayaan proyek dengan memperhatiakan pasok material, persediaan, fasilitas, kesesuaian data dan keselamtan. Dengan adanya hasil penelitian identifikasi pada makalah ini diharapkan dapat membuka wacana pemahaman bagi semua pihak.

\section{DAFTAR PUSTAKA}

Sherlywati, 2017 Urgensi Penelitian Manajemen Rantai Pasok: Pemetaan Isu, Objek, Dan Metodologi. Jurnal Manajemen Maranatha, Vol 17 No. 2 ISSN 2579-4094 
Andi M, Irma S, Oktaviana K.A. 2018. Pengaruh Rantai Pasok Terhadap Kinerja Kontraktor Di Propinsi Banten Dan DKI Jakarta, Jurnal Kontruksia, Vol 9 No. 2

Ardiansyah K. 2016. Analisis Nilai Hasil Terhadap Waktu Dan Biaya Pada Proyek Kontruksi. Jurnal Sipil

Yunita A, Lazry H, Dantje A. 2013. Pengendalian Waktu Dan Biaya Pekerjaan Konstruksi Sebagai Dampak Dari Perubahan Desain. Jurnal Teknik Sipil Vol. 2 No. 2

Rifqi A, Daniar R, Suharyanto, Frida K. 2017. Pengendalian Biaya Dan Waktu Proyek Dengan Metode Konsep Nilai Hasil (Earned Value). Jurnal Karya Teknik Sipil. Vol. 6 No. 4- $460-470$

Sediyanto, Aris H. 2017. Analisa Kinerja Biaya Dan Waktu Pada Pelaksanaan Proyek Konstruksi Dengan Metode Earned Value (Studi Kasus Proyek Konstruksi Mall Dan Hotel X Di Pekanbaru). Jurnal Teknil Dan Ilmu Komputer. Vol. 1 No. 1 ISSN 2548-74 DX

Prof. Dr. Manahan P. Tampubolon, S.E, MM. 2014. Manajemen Operasi Dan Rantai Pemasok, Jakarta.

Barrie Donald S, Paulson JR. Boyd C, dan Sudinarto. 1995. Manajemen Konstruksi Profesional, Edisi Kedua. Erlangga, Jakarta Ir. Irika Widiastuti, MT. 2013. Manajemen kontruksi. Remaja Rosdakarya. Bandung

Richard I. Levin Dkk. 1997. Pengambilan Keputusan Secara Kuantitatif. Raja Grafindo. Jakarta Lock Dennis. 1987. Manajemen Proyek; Edisi ketiga. Erlangga. Jakarta.

Bush Vincent G. 1985. Manajemen Konstruksi; Buku Pegangan untuk Kontraktor, Arsitek, dan Mahasiswa, Seri Manajemen No. 74. Pustaka Binaman Pressindo. Jakarta Anatan, L. (2017). Isu Penelitian Manajemen Rantai Pasok. (S. Sherlywati, Interviewer)

Primiana, I. (2017). Prioritas Industri Strategis. Pemetaan Supply Chain Management Sudah Mendesak . Bandung, Jawa Barat, Indonesia: Pikiran Rakyat.

A. Husen, Manajemen Proyek, Yogyakarta:Andi, 2011 